\title{
FRAUD TRIANGLE DI SEKTOR PEMERINTAHAN (Studi Kasus Pada Dinas Kabupaten Buleleng)
}

\author{
Ni Luh Putu Indah Trisna Dewi, Made Pebri Anggariyani, I Dewa Ayu Eka \\ Septyastini, Ni Made Sinta Gayatri, Kadek Dian Sudiari, Kadek Dwi Andika \\ Jurusan Akuntansi, Universitas Pendidikan Ganesha, Singaraja, Buleleng, Bali
}

\begin{abstract}
Abstrak
Penelitian ini bertujuan untuk menginvestigasi adanya potensi penyimpangan pada organisasi pemerintahan. Investigasi dilakukan dengan menggunakan pendekatan Fraud Triangle pada dinasdinas di Kabupaten Buleleng-Bali. Pengumpulan data dilakukan melalui metode wawancara dan dokumentasi. Hasil penelitian menunjukkan bahwa terdapat potensi kecurangan pengelolaan keuangan akibat kurangnya pengawasan yang dilakukan. Dalam kaitannya dengan Fraud Triangle, inin berhubungan dengan aspek opportunity (kesempatan) yang memungkinkan tindakan kecurangan dapat terjadi.
\end{abstract}

Kata kunci: Fraud triangle; organisasi pemerintahan; Buleleng

\begin{abstract}
This study aims to investigate the potential for irregularities in government organizations. Investigations were carried out using the Fraud Triangle approach in agencies in the Regency of Buleleng, Bali. Data collection is done through interviews and documentation. The results showed that there was potential for financial management fraud due to lack of supervision conducted. In connection with the Fraud Triangle, this is related to the opportunity aspect (opportunity) that allows fraud to occur.
\end{abstract}

Keywords: Fraud triangle; government organization; Buleleng

\section{Pendahuluan}

Instansi pemerintah mempunyai peranan penting dalam pencapaian tujuan suatu pemerintahan. Terkait dengan pencapaian tujuan pemerintah tersebut maka harus didukung dengan perilaku atau tindakan baik dari para pegawainya. Namun, pada kenyataannya banyak kasus fraud yang terjadi di kalangan instansi pemerintahan baik pusat maupun daerah. Fraud adalah sebuah tindakan yang menyebabkan kesalahan pelaporan dalam laporan keuangan, atau suatu tindak kesengajaan untuk menggunakan sumberdaya perusahaan secara tidak wajar dan salah menyajikan fakta untuk memperoleh keuntungan pribadi. Fraud menurut standar Institute of Internal Auditors (IIA) dalam sawyer (2006:339) adalah suatu tindakan penipuan yang mencakup berbagai penyimpangan dan tindakan illegal yang ditandai dengan penipuan disengaja. Kasus fraud sendiri tidak hanya dilakukan oleh instansi pemerintahan pusat, melainkan sudah menjamur hingga keinstansi-instansi daerah. Salah satu yang bisa dikatakan sebagai tindakan fraud adalah kasus korupsi yang sudah sangat tidak asing di telinga kita. Hasil pemantauan yang dilakukan Indonesia Corruption Watch ( ICW), menunjukkan bahwa sebanyak 755 kasus korupsi yang terjadi per tahun 2016. Namun hanya 112 kasus tindak korupsi yang berhasil di tuntaskan KPK melalui kejaksaan dan sisanya penanganan kasus korupsi tersebut tidak berlangsung.

Mengenai masalah fraud itu sendiri,sudah banyak ahli-ahli yang menerapkan konsep fraud yaitu "fraud triangle" dalam membuktikan ataupun menyelesaikan suatu masalah yang ditemukannya. Salah satunya adalah Kurniawati (2012) mencoba meneliti kecurangan laporan keuangan dengan menggunakan segitiga kecurangan (fraud triangle) yaitu dengan menggunakan model regresilogistik untuk menemukan faktor yang berpengaruh terhadap kecurangan laporan keuangan. Hasilnya yaitu ditemukan bukti bahwa pertumbuhan tinggi dari perusahaan, kerugian laba, kemampuan perusahaan memenuhi kewajibannya, dan transaksi pihak istimewa berpengaruh secara positif dan signifikan terhadap kecurangan laporan keuangan. Jadi kami disini ingin menganalis dan membuktikan adakah kasus tindak 
fraud triangle dalam instansi pemerintahan di Kabupaten Buleleng. Dengan menganalisis faktor-faktor yang terdapat dalam fraud triangle yaitu pressure, opportunity, dan rationalization ini akan digunakan untuk menjelaskan hubungan antar variabel yang berkaitan langsung dengan kejadian fraud. Berdasarkan latarbelakang tersebut, maka penelitian ini berjudul "Fraud Triangle di Sektor Pemerintahan (Studi Kasus Pada Dinas Kabupaten Buleleng)".

Salah satunya adalah isu-isu yang beredar pada Dinas Pendidikan mengenai anggaran pendidikan yang diberlakukan dan pada PD Pasar mengenai kasus pungutan liar yang dari tahun ke tahun masih dipermasalahkan. Faktanya dari tahun ke tahun PD Pasar Kabupaten Buleleng selalu masuk berita mengenai kasus pungutan liar, salah satu beritanya yaitu :

\section{Dirut PD Pasar Buleleng Bantah Pungli}

Singaraja (Antara Bali) - Laporan para pedagang daging dan buah di Pasar Seririt yang didukung karyawan Perusahaan Daerah Pasar Buleleng Unit Seririt yang menyebutkan telah terjadi pungutan liar, dibantah oleh Dirut PD Pasar Buleleng, Putu Gede Satwika Yadnya, M.Sc.

Saat dikonfirmasi di Singaraja, wilayah utara Bali itu, Minggu, dia membantah telah terjadi pungutan liar seperti isu miring yang dilaporkan oleh para pedagang dan 18 karyawan PD Pasar Unit Seririt dan disampaikan kepada Bupati Buleleng. "Semua yang mereka tulis dan dilaporkan ke bupati itu tidak benar. Seluruh karyawan juga mendapat THR sesuai dengan kepangkatannya. Jadi, THR itu kami bagi merata," ujar Satwika Yadnya menandaskan. la juga membantah telah mengancam akan memecat atau memindahkan karyawan yang sempat menanyakan hak-hak mereka kepada direksi PD Pasar. "Tidak ada ancaman seperti itu. Saya tidak pernah mendahulukan cara-cara seperti itu," ucapnya.

Namun dia mengakui bertindak tegas terhadap karyawan yang melanggar aturan perusahaan. "Saya memang ancam, tapi mengancam karyawan yang melanggar aturan perusahaan," kata Satwika Yadnya. Kalau ada karyawan yang melanggar aturan, ujarnya, akan dikenakan sanksi sesuai aturan yang ada perusahaan daerah tersebut.( $\left.{ }^{\star}\right)$ Editor: Nyoman Budhiana

Kasus fraud yang terjadi sesungguhnya selalu menjadi permasalahan yang tidak pernah ada ujungnya, saat ada satu kasus yang telah terselesaikan maka kasus barulah yang berdatangan. Hal inilah yang membuat negara sulit maju, untuk itu telah banyak usaha dan teori yang yang dituangkan untuk mencegah dan mengatasi permasalah fraud. Namun lantaran fraud lebih condong ke perasalah individu, maka solusi yang paling tepat sesungguhnya pada individu itu sendiri.

Mengenai pembuktian adanya tindakan fraud pada sektor pemerintahan sangat sulit dilakukan dan pada pemerolehan data serta untuk melakukan penelitiannya pun sangat dipersulit pada setiap dinasnya. Sehingga hal inilah yang menimbulkan bawah tindakan fraoud dicurigai telah terjadi dan lebih ditutup-tutupi oleeh para tenaga kerja setiap dinasnya. Fraud yang dahulunya merupakan tindakan kecil namun memberikan dampak yang sangat besar pada masyarakat. Akibat dari seringnya terjadi penggelapan dan tidak pernah ada pengakuan yang jujur pada kalangan tenaga kerja untuk mengakui adanya tindakan fraud dan bahkan belum ada yang berani melapor secara langsung pada adanya tindakan tersebut. Untuk itu penulis pun ingin mengetahui kebenaran dengan melakukan penelitian terhadap tindakan fraud dan membuktikan ada atau tidaknya.

Masalah fraud harus segera diselesaikan dan ditemukan permasalah intinya, sehingga setiap kasus yang ada dapat diselesaikan satu per satu. Segala tindakan penyelewengan dan kekuasaan yang tidak bertanggung jawab harus dihindari, hal ini bertujuan untuk memajukan sektor pemerintahan yang fungsinya mensejahterakan dan memenuhi keinginan masyarakatnya. Dengan melihat kassus-kassus korupsi yang terjadi tahun belakangan menunjukan bahwa ego dan kepentingan diri sendiri muncul saat seseorang terlah merasa menguasai.

Dari latar belakang di atas memunculkan rumusan masalah yaitu apakah ada penyimpangan di dinas kabupaten buleleng. 


\section{Hasil dan Pembahasan}

\subsection{Pengertian Fraud Triangle}

Anda percaya kepada seseorang, apakah anda berprasangka buruk terhadap orang tersebut? Tidak. Nah, bagi orang kepercayaan yang tidak pantas dipercaya akan memanfaatkan kepercayaan anda untuk menutupi dan melancarkan aksi kejahatan mereka. Terus, apakah tidak boleh mempercayai orang lain? Boleh, tapi yakinkan bahwa kepercayaan anda ada pada orang yang tepat. Kuncinya adalah: Jangan gampang percaya! Disini kami akan mencoba menjelaskan kemungkinan terjadinta penipuan/Fraud yang terjadi di beberapa sektor pemerintahan.

Fraud merupakan kejahatan manipulasi informasi dengan tujuan mengeruk keuntungan yang sebesar-besarnya. Biasanya kejahatan yang dilakukan adalah memanipulasi informasi keuangan. Fraud adalah proses pembuatan, beradaptasi, meniru atau benda, statistik, atau dokumen-dokumen, dengan maksud untuk menipu. Kejahatan yang serupa dengan penipuan adalah kejahatan memperdaya yang lain, termasuk melalui penggunaan benda yang diperoleh melalui pemalsuan. Menyalin, penganda, dan mereproduksi tidak dianggap sebagai pemalsuan, meski pun mungkin mereka nanti dapat menjadi pemalsuan selama mengetahui dan berkeinginan untuk tidak dipublikasikan. Dalam hal penempaan uang atau mata uang itu lebih sering disebut pemalsuan. Barang konsumen tetapi juga meniru ketika mereka tidak diproduksi atau yang dihasilkan oleh manufaktur atau produsen diberikan pada label atau merek dagang tersebut ditandai oleh simbol. Ketika objek adalah catatan atau dokumen ini sering disebut sebagai dokumen palsu.

Fraud juga diartikan dengan Penipuan, yang memiliki arti keliru yang disengaja yang menyebabkan seseorang atau bisnis menderita kerusakan, sering dalam bentuk kerugian moneter. Semua elemen ini biasanya diperlukan untuk tindakan yang harus dipertimbangkan penipuan, jika seseorang berbohong tentang namanya, misalnya, tidak akan penipuan kecuali dengan demikian, orang yang menyebabkan orang lain kehilangan uang atau menderita beberapa kerusakan lainnya. Ada berbagai jenis penipuan, dari pencurian identitas, penipuan asuransi untuk memalsukan informasi pajak, dan membuat pernyataan palsu sering dapat menjadi salah satu elemen kejahatan lain. Meskipun biasanya dituntut di pengadilan kriminal, penipuan juga dapat mencoba di bawah hukum sipil.

Berdasarkan beberapa definisi tersebut di atas, dapat dilihat bahwa fraud atau kecurangan memiliki empat Kriteria yang harus dipenuhi, yaitu:

1) Tindakan tersebut dilakukan oleh pelaku secara sengaja

2) Adanya korban

3) Korban menuruti kemauan pelaku

4) Adanya kerugian yang dialami oleh korban

Dilihat dari pelaku fraud maka secara garis besar kecurangan bisa dikelompokkan menjadi dua jenis :

1) Oleh pihak perusahaan, yaitu :

a. Manajemen untuk kepentingan perusahaan, yaitu salah saji yang timbul karena kecurangan pelaporan keuangan (misstatements arising from fraudulent financial reporting).

b. Pegawai untuk keuntungan individu, yaitu salah saji yang berupa penyalahgunaan aktiva (misstatements arising from misappropriation of assets).

2) Oleh pihak di luar perusahaan, yaitu pelanggan, mitra usaha, dan pihak asing yang dapat menimbulkan kerugian bagi perusahaan.

Dalam pengertian luas, Fraud adalah suatu bentuk penipuan yang disengaja/direncakan demi keuntungan dan kemakmuran pribadi/perseorangan atau untuk merusak/mengganggu kehidupan dan kekayaan orang lain. Kata "deception" atau "penipuan" adalah kata kunci untuk mendefinisikan Fraud. Perlu diketahui bahwa Fraud selalu melibatkan penipuan dan kepercayaan. Satu hal yang perlu dicamkan adalah "orang yang paling dipercaya adalah orang yang memiliki peluang paling besar untuk melakukan penipuan kepada anda. 
Semakin berkembangnya mengenai teori Fraud dan pelakunya maka munculah istilah Fraud Triangle dimana dalam fraud tersebut terdapat beberapa faktor yang mempengaruhinya. Seperti namanya,Fraud Triangle artinya secara logika bisa dikatakan segitiga kecurangan.Dalam Fraud Triangle itu sendiri terdiri dari Pressure (Tekanan), Opportunity (Peluang), Razionalitation (Pembenaran). Banyak pengertian mengenai bagianbagian Fraud Triangle dari para ahli yang mendukung teori ini.Untuk lebih jelasnya, penjelasannya tersebut akan di jelaskan dalam gambar yang di bawah ini.Fraud triangle ini sendiri juga akan membantu kami dalam menyelesaikan studi kasus mengenai Fraud Triangle di Sektor Pemerintahan Kabupaten Buleleng.

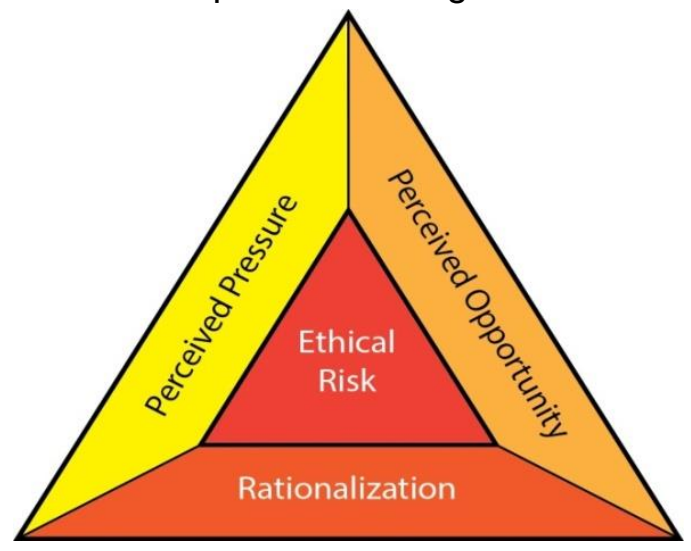

\section{1) Pressure}

Pressure merupakan dorongan untuk berbuat curang terhadap laporan keuangan dan berbagai unsur yang ada didalamnya baik asset maupun modal yang ada.Dari tiga jenis fraud triangle, pressure merupakan yang paling berbahaya. Karena pelaku kecurangan berbuat demikian atas dasar homo homini lupus (istilah dalam ilmu sosiologi) yang berarti memakan manusia.Ya, pressure muncul akibat keserakahan.Selain keserakahan faktor pressure juga mucul akibat tekanan ekonomi orang itu sendiri.Dan inilah yang menjadi faktor number wahid atas terjadinya kecurangan di beberapa entitas kelas berat macam Enron, Worldcom, Lehman Brother, dan skandal-skandal lainnya. Di dalam negeri pun kita pasti masih ingat betul kasus Bank Century dan Bantuan Likuiditas Bank Indonesia (BLBI) yang sampai saat ini masih jalan di tempat atau mungkin telah terkubur di liang lahat..Faktor munculnya pressure dalam berbuat kecurangan menjadi cambuk yang sangat keras bagi para pelaku bisnis, pengusaha, internal control, dan siapun yang berkepentingan dengan bisnis sebuah perusahaan.Kasus KAP (Kantor Akuntan Publik) The Big Five Arthur Andersen yang melepas jubah independensi dan objektivitasnya sebagai akuntan publik yang termakan buaian dan rayuan Enron memberikan kita pelajaran penting. Yaitu selalu ada keserakahan dalam dunia bisnis.

\section{2) Opportunity}

Peluang yang memungkinkan fraud terjadi biasanya disebabkan karena internal control suatu organisasi yang lemah, kurangnya pengawasan, dan/atau penyalahgunaan wewenang. Pelaku fraud juga bisa dikategorikan sebagai orang yang pintar,karena mampu memanfaatkan peluang yang ada dalam suatu perusahaan atau kantor dinas untuk keuntungan bagi dirinya sendiri. Di antara 3 elemen fraud triangle, opportunity merupakan elemen yang paling memungkinkan untuk diminimalisir melalui penerapan proses, prosedur, dan control dan upaya deteksi dini terhadap fraud.

\section{3) Rationalization}

Berbeda dengan pressure dan opportunity, faktor ketiga ini menjadi penyebab fraud karena adanya pembenaran atas apa yang dilakukan (rasionalisasi). Pihak yang melakukan fraud merasa bahwa apa yang ia lakukan benar atas dasar alasan-alasan yang menurutnya logis. Dan menurutya,saat ia melihat rekan kerjanya yang melakukan fraud,itu merupakan hal yang wajar,lalu bukannya melaporkan ke atasan malah ikut melakukan tindakan fraud 
tersebut.Hal itu bisa di bilang jika orang tersebut bertindak tidak etis terhadap profesinya Misalnya, masa kerja pelaku cukup lama dan dia merasa seharusnya berhak mendapatkan lebih dari yang telah dia dapatkan sekarang (posisi, gaji, promosi, dll). Atau perusahaan telah mendapatkan keuntungan yang sangat besar dan tidak mengapa jika pelaku mengambil bagian sedikit dari keuntungan tersebut.

Setelah kita membahas masalah pengertian fraud dan cabang-cabangnya, kali ini kami akan menggali sedikit mengenai masalah segitiga fraud (Fraud Triangle).Sebenarnya Fraud Triangle adalah teori lama. Pencetusnya adalah Donald R.Cressey dimana dalam disertasi doctornya ,beliau meneliti pada 200 narapidana pelaku fraud ,tepatnya orang yang mencuri uang perusahaanya. Dalam wawancaranya, Cressey menggali alasan narapidana tersebut tergoda untuk melakukan "trust violator" (penghianatan terhadap kepercayaan). Setelah ,menyelesaikan penelitiannya, Cressey mengembangkan suatu teori yang sampai sekarang masih digunakan .Hipotesis teori yang dibangun adalah: "Seseorang yang dipercaya oleh perusahaan menjadi seorang "penghianat kepercayaan" karena ia telah melihat dirinya sendiri sebagai orang yang mempunyai masalah keuangan yang tidak dapat diceritakannya kepada orng lain ,sadar bahwa masalah ini dapat diatasi secara diam-diam dengan menyalahkan wewenangnya sebagai pemegang kepercayaan dibidang keuangan,dan tidak tanduk sehari-hari memungkinkannya untuk menyesuaikan pandangan mengenai dirinya sebagai orang yang dapat dipercaya dalam menggunaka dana atau kekayaan yang dipercayakan kepadanya.

Begitulah fraud triangle menjawab bagaimana dan apa alasan terjadinya fraud atau kecurangan dalam sebuah perusahaan. Mungkin orang awam akan bertanya, lalu apa masalahnya kalau mereka melakukan kecurangan? Bukankah mereka itu pemilik perusahaan atau pegawai di suatu perusahaan/kantor dinas? Atau, memangnya dampak apa yang akan terjadi, kan yang berbuat curang para manajemen perusahaan?

Maka dari itu di bagian selanjutnya kami akan menjelaskan Fraud Triangle ini dalam sebuah studi kasus,dimana kita menggunakan 2 sampel objek observasi,yaitu PD Pasar Kabupaten Buleleng dan Dinas Pendidikan Kabupaten Buleleng.

\section{Simpulan dan Saran}

Dari hasil penelitian mengenai penyelidikan perilaku fraud pada sektor publik, pada kesempatan penelitian kali ini penulis hanya menggunakan dua sampel, yaitu Dinas Pendidikan dan PD Pasar telah diperoleh beberapa hasil yang mampu memberikan jawaban dari hasil penelitian yang penulis telah lakukan, adapun hasil yang diperoleh adalah sebagai berikut.

Pada Dinas Pendidikan penyelenggaraan sistem keuangannya sudah tersistem dengan baik namun untuk atau tidaknya tindakan fraud penulis lebih condong pada jawaban ada atas dasar bukti penelitian yang telah penulis lakukan.

Pada PD Pasar penulis melakukan penelitian dari informasi sebelum-sebelumnya, yaitu dengan adanya isu pungutan liar yang dilakukan. Penulis menemukan data berupa hasil wawancara dan kuisioner yang telah dilaksanakan bahwa dari segi pengawasan pada PD Pasar sudah diperbaiki dari setiap kepengurusan dan sudah mampu mengatasi tindakan penyelewenagn yang ingin dilakukan karyawan. Tetapi untuk secara menyelutuh tindakan fraud masih sulit untuk dihindari walaupun masih dengan jumlah yang relative kecil.

Jadi, dari kedua dinas yang telah dilakukan masih terjadi sebuah tindakan penyelewengan dan sistem pengawasan yang kurang. Sehingga kinerja dari setiap dinas harus lebih di perbaiki kembali.

Saran yang dapat penulis berikan atas simpulan di atas, yaitu :

1. Untuk Pemerintah

Diharapkan dengan adanya makalah ini, penulis berharap pemerintah mampu memperbaiki sistem kerja pada setiap dinasnya demi kelangsungan dan kesuksesan pada profesi karyawan itu sendiri. Perlu diingat bahwa tugas pemerintah adalah untuk ikut serta membantu melakukan pembangunan pada negara Indonesia dan membantu mensejahterakan rakyat dengan kebijakan yang telah di buat.

2. Untuk Pembaca 
Diharapkan dengan adanya makalah ini, para pembaca mampu mengetahui informasi seputar kinerja dinas pemerintahan, hal ini berfungsi untuk masyarakat dalam mengajukan aspirassi kepada pemerintah nantinya. Sehingga pembaca harus mampu mencermati dan menyimak setiap perkembangan dan perlakuan kebijakan yang telah ditetapkan pemerintah.

3. Untuk Penulis

Diharapkan dengan adanya makalah ini, penulis dapat memperoleh informasi seputar kinerja dinas pemerintahan dan mampu memberikan kritik dan saran yang membangun.

\section{DAFTAR PUSTAKA}

http://cyberlawfraud.blogspot.co.id/2013/04/normal-0-false-false-false-en-us-x-none.html http://www.investigator.id/2016/03/fraud-triangle-segitiga-fraud.html https://bursanom.com/fraud-triangle/ 